age of Utopias-ideal societies, whose perfection and desirability were believable-in for their contemporaries. And as in the eighteenth and nineteenth centuries the idea of progress became an article of faith-or with Darwin, a scientific fact-Utopias changed from eudaemonic wishing to optimistic prophecy. Utopias provide, therefore, important indices-not so much to progress itself-but to what people imagine progress over their actual condition would be. But by the middle of the twentieth century, the conception of Utopias came more or less to an end after Aldous Huxley had shown in Brave New World that what people had all along thought was progress actually leads to a horrible rather than wonderful human condition.

The reason why it is so difficult now to imagine a new Utopia is that the knowledge and insights we have acquired about the world since the seventeenth century have shown that the ensemble of human (all-too-human) aims and desires is self-contradictory and hence in principle unattainable. This was of little import at the long remove from the realization of any of these aims in the seventeenth century; but by the middle of the twentieth century the tremendous increase in human mastery of nature had finally brought these contradictions into the open. It is for just that reason that there has lately occurred what Medawar refers to as "a revival of faith in the Wisdom of the East". For though this wisdom may be the nonsense that Medawar evidently finds it, it does, in its nonsensical way, try to resolve some of the contradictions by restructuring the ensemble of human aims. Hence I fear that even as eloquent a sermon as Sir Peter's will not revive faith in the Wisdom of the West. What it would take is to put forward a believable-in Utopia to which progress could lead us in the twenty-first century. And that may be an impossible mission.

Gunther S. Stent

\section{Biography of Appleton}

Sir Edward Appleton, GBE, KCB, FRS. By Ronald Clark. Pp. xiii $+240+24$ plates. (Pergamon: Oxford and New York, January 1972.) $£ 4$; $\$ 10.75$.

Mr Clark's informative account of Appleton's life and achievements is welcome. $\mathrm{He}$ was an eminent discoverer, as his determination of the height of the ionosphere and many features of its structure and mechanism manifested. $\mathrm{He}$ had a passionate interest in scientific research for its own sake, and an equal devotion to "getting on". He was born in Bradford, the son of poor, strict Wesleyan Methodists.
Virtually the only mark that separated his father, a warehouseman, from the working class was that he wore a bowler hat, not a cloth cap. Appleton went to the local elementary school, and won a scholarship to a secondary school. $\mathrm{He}$ got a first in the London Matric, and became a "temporary laboratory assistant" at Bradford Technical College. His old science teacher happened to meet him in the street, and advised him to compete for a local scholarship tenable at a university. Appleton won it, and went to Cambridge. He was a very typical Yorkshireman, keenly interested in cricket, with the stocky, muscular physique of the famous Yorkshire cricketer of the day, George Hirst, the greatest retriever of victory out of defeat in the game.

Appleton won prizes for mineralogy and physics, and in 1914 joined Lawrence Bragg as his first research student, beginning research on the crystal structure of copper. Very shortly after, the First World War started. After serving 116 days in the ranks, his application for a commission came through. He was sent for training for the Army Signal Service and attended the first radio course for officers at Malvern. This was the beginning of his concentration on radio; except for the war he would probably have become an X-ray crystallographer.

His first papers, published in 1918, were on thermionic valves. He returned to Cambridge in 1919, and when Rutherford became Cavendish Professor was appointed an assistant demonstrator. He started research on $\alpha$ particles, but wanted to follow his own line, in which he was encouraged by Rutherford. $\mathrm{He}$ was stimulated by C. T. R. Wilson's work on thunderstorms to correlate them with atmospherics. This brought him in contact with Watson-Watt; they collaborated for a time, but presently sharply diverged.

Research in 1924 led to the discovery that radio signals were arriving by two routes, one along the ground, and the other by reflexion from above. Hampered by a heavy load of teaching and being out of Cavendish atomic research, he applied for the Wheatstone chair at King's College, London, and was appointed.

He succeeded C. T. R. Wilson as Jacksonian Professor in 1936, and when Rutherford died unexpectedly in 1937 he became Acting Director of the Cavendish. In 1938 he became Secretary of the DSIR. He concentrated on holding it together during the Second World War, so that it might assist industry to recover more quickly when the war was over. Though he was on military scientific committees his outlook was civilian. He kept his personal research on the ionosphere going, and he could be found in his DSIR office correcting the typescript of his latest ionosphere paper, while the V-1 bombs were exploding overhead.

After he became Principal of Edinburgh University in 1949, and engaged in the immense task of extending it, he still sustained his radio researches, to the end of his life.

\section{J. G. CROWTHER}

\section{There was Corn in Egypt}

Who Will Eat?-The World Food Problem: Can We Solve It? By Michael Allaby. Pp. 252. (Tom Stacy: London, September 1972.) $£ 2.90$.

R. A. McCANCE, in a review of the literature of hunger oedema written as a preface to an experimental investigation of the state of nutrition in 1946 in Wuppertal in the Ruhr, listed sixteen closely printed pages of references to earlier occasions when hardship, malnutrition and famine had previously been reported in various parts of the world. These ranged through recorded history from Hesiod's time in $700 \mathrm{BC}$, that of Diogenes Laertius in $\mathrm{AD} 300$, from The Chronicle of Novgorod in the eleventh century to J. M. Good's Dissertation on the Diseases of Prisons and Poor-houses of 1795 and so on to Ancel Keys in 1946. Famine, starvation and hunger have, alas, been part of the human condition since the beginning of recorded time. McCance and his colleagues could hope, by using the tools of science and the knowledge of their predecessors, to discover something of the physiological mechanisms by which lack of food causes the damage it does. There is less evidence to support the belief that polemical writers, focusing their attention on the here and now as seen by other reporters of the current scene, can draw up a plan by which all the inhabitants of the world can uniformly be assured of a nutritionally satisfactory diet. Even in biblical times, as we are told in Genesis, chapter 41, verse 57, "all countries came into Egypt to Joseph" (that excellent, if pre-scientific, administrator) "for to buy corn: because that the famine was so sore in all lands".

No one can quarrel with Michael Allaby's conclusion either that the human population cannot grow in numbers indefinitely or that the remarkable increases in food supplies brought about by agricultural science must some day reach their limits and stop, although it hardly reinforces his argument relating underfeeding with overcrowding to cite Great Britain as an example of an overpopulated territory. And it is even less easy to be convinced by his thesis that because after nearly half a century of the successful use of one kind of sheep dip or another kind of plant pesti- 